\title{
A Survey of the Environmental Conservation Costs by Local Authorities in Kenya
}

\author{
Samuel Kilika ${ }^{a}$, Nicholas Mutua ${ }^{b}$ \\ ${ }^{a}$ Taita Taveta University College, 635, VO I-80300, Kenya \\ ${ }^{b}$ Taita Taveta University College, 635, VO I-80300, Kenya
}

\begin{abstract}
This study investigates the environmental conservation costs of the local authorities in Kenya by analyzing the data collected from 90 of these local authorities. The population of the study is the 175 local authorities in Kenya. A sample of 90 local authorities has been used. Both statistical package for social sciences (SPSS) version 17 and Excel have been used to determine the level of environmental conservation costs in the studied local authorities. The results indicated that there was a wide use of environmental conservation costs among the local authorities. The study provides preliminary evidence on environmental conservation costs used by local authorities in Kenya. Further research is suggested to explore the possible motivating factors among different local authorities' degree of application and level of environmental costs in different activities.
\end{abstract}

Keywords: Environmental Conservation; Local authorities; Environmental costs

\section{(C) 2013 Published by SSBFNET}

\section{Introduction}

This paper investigates the environmental conservatıon costs by local authorities in Kenya. Environmental conservation cost refers to the investment and costs measured in monetary values, allocated for prevention, reduction, and or avoidance of environmental impact, removal of such impact, restoration following the occurrences of a disaster and other activities. These are costs borne by companies and organizations for environmental conservation i.e. private costs. The costs do not include costs borne for health damage or environmental pollution suffered by third parties or society as a whole resulting from the business activities of companies and other organizations i.e. social costs. It means the burden placed upon society as a result of the environmental impact of a specific company or other organizations, or of an unspecified entity. Social cost is also referred to as "external cost" or "external discovery" such as damage suffered by a third party or damage caused to forests or agriculture due to environmental impact resulting from the business activities of a company or other organization will not result in a direct economic burden for that company provided that there is no proof of causal relationship but the society as a whole may be considered to have sustained a loss Medley (1997).

Environmental conservation cost can be categorized into one, business area costs which are costs for activities to reduce environmental impact which occur within the business area due to key business operations. The business area is the region where the organization can directly manage environmental impacts. Business area cost is associated with environmental conservation is divided into pollution prevention cost, global environmental cost and resource recycling cost. Secondly, administration cost which is the cost for management activities conducted by companies and other organizations for environmental conservation activities. The cost includes the cost for efforts that directly contribute to reducing the environmental impact generated through business activities, and the cost for efforts for communication

${ }^{\mathrm{a} C}$ Corresponding author.Kilika Samuel, Tel.: +020 086808. 
with society by companies and other organizations, like the cost for environmental training for employees, cost for environmental improvement activities such as nature conservation, greening, and beautification. Thirdly, environmental remediation costs. These are costs allocated for recovery of the environmental degradation due to business activities like the cost to restore natural environment back to its original state, provision or insurance fees to cover degradation to the environment. Fourth, social activity cost which is a cost related to environmental conservation conducted for the good of the broad range of society Gulch (2000). This is considered a cost for environmental conservation efforts consisting of social activities with no direct relationship to the business activities of the company or other organizations like cost for environmental activities like planting of greenery, beautification and landscape preservation. Fifth is the R\&D cost which constitutes spending for research and development activities allocated to environmental conservation. Lastly are the upstream/ downstream costs. Upstream cost is a cost for efforts to reduce the environmental impact that is created prior to the input of goods and services into business areas, as well as the cost related to such efforts i.e. provision of materials for goods and services. Downstream cost is a cost for efforts to reduce the environmental impact that is created after goods and services have been output from business areas, as well as the cost related to such efforts i.e. use and consumption of goods and services Medley (1997).

The study seeks to determine environmental costs by local authorities in Kenya. The study acts as an exploratory on environmental accounting forming a basis for further research and illustrate important findings for the groups including the local authorities in Kenya and the stakeholders of local authorities like consumers of their services, business partners, investors, employees of particular local authorities and the residents. The local authorities can be able to establish the benefits they get from environment conservation as well as the costs of undertaking environmental activities, tuture researchers, local government of Kenya as well as other scholars.

\section{Literature Review}

The section presents both theoretical (untested) as well as empirical (tested) literature relevant to the subject of study.

Accounting for environmental costs and performance can support a company's / organization's development and operation of an overall environmental management system. Understanding the environmental costs and performance of processes and products can promote more accurate costing and pricing of products and can aid organizations in the design of more environmentally preferable processes, products and services for the future. Better management of environmental costs can result in improved environmental performance and significant benefits to human health as well as business success. The disclosure of environmental accounting regarding environmental conservation activities of companies and other organizations, including public interest organizations and local public entities, provides a means for stakeholders to understand, evaluate, and give their support to such efforts.

Environmental accounting continues to take root as part of the social system. Taking into account, developments in environmental accounting at companies and other organizations, it has the objective of supporting the introduction and implementation of environmental accounting at companies and other organizations. Environmental accounting is also intended to insure that the information disclosed takes into consideration the needs of the various stakeholders. Another objective is to improve the effectiveness of environmental accounting methodology, so that by employing given guidelines in organizing environmental accounting data, companies and other organizations can monitor their data not only for publication, but also further their objective of internal environmental management (Bailey, 1991).

The quantitative management of environmental conservation activities is an effective way of achieving and maintaining sound business management. In other words, in carrying out environmental conservation activities, a company or other organizations can accurately identify and measure investments and costs related to environmental conservation activities, and can prepare and analyze this data. By having better insight into the potential benefits of these investments and costs, the company can not only improve the efficiency of its activities, but also utilize environmental accounting as a discipline which plays a very important role in supporting rational decision-making. In addition, companies and other organizations are required to have accountability to stakeholders, such as consumers, business partners, investors, employees, local residents, and administration, when utilizing environmental resources, i.e. public goods, for their business activities. Disclosure of environmental accounting information is a key process in performing accountability. Consequently, environmental accounting helps companies and other organizations boost their public trust and confidence and are associated with receiving a fair assessment (Lehman, 2000). The functions of environmental accounting are divided into internal and external functions. As one step of an organization's environmental information system, internal function makes it possible to manage environmental conservation cost and analyze the cost of environmental conservation activities versus the benefit obtained, and promotes effective and 
efficient environmental conservation activities through suitable decision-making. It is desirable for environmental accounting to function as a business management tool for use by managers and related business units. On the other hand, by disclosing the quantitatively measured results of its environmental conservation activities, external functions allow an organization to influence the decision-making of stakeholders, such as consumers, business partners, investors, local residents, and administration. It is hoped that the publication of environmental accounting results will function both as a means for organizations to fulfill their responsibility for accountability to stakeholders and, simultaneously, as a means for appropriate evaluation of environmental conservation activities (Lehman, 2000).

Local authorities in Kenya are the bodies controlling local governance in Kenya. Local Authorities in Kenya are governed by the local government Act cap 265 laws of Kenya. Kenya has 175 local authorities which are categorized into city councils, town councils, municipal councils and county councils. The Act spells out wide ranging powers and functions for local authorities, where most of these functions undertaken by the local authorities relate to provision of public services, promotion of good governance and simulation of good economic growth. The functions and responsibilities cover basic services such as markets, garbage collection, street lighting maintenance, development planning, roads, sewerage, community welfare, slaughterhouses and burial of destitute people. There are also provisions of health to the community through health centers as well as dispensaries. Besides health facilities the council provides housing, schools and recreational facilities and maintenance of parks (Local government Act caps 265 laws of Kenya). Local authorities get their funding from the local authorities transfer fund (LATF) which is a block grant that transfers 5\% of the national income to the local authorities. It distribution is ksh 1.5 million to each of the 175 local authorities in Kenya (per annum). This is $60 \%$ in proportion to the total population of each local authority, $40 \%$ in proportion to the urban population of each local authority. The second source of funds is road maintenance levy fund (RMLF) which is collected from fuel levy on petroleum products and transit toll collections. The third source of funds is the contribution in lieu of rates (CILOR) which a local tax levied on property like land by the local authority as authorized by the central government .MLG Circular (2009).

Mazhindu (2009) in his study on local government processes and the environment in Africa stated that by and large, the conventional planning approaches have either ignored or underestimated the growing environmental concerns. The search for planning responses to the devastating environmental concerns has culminated in the assembly of an 'environmental tool box' containing an assortment of instruments notably, po llution control and licensing, Environmental Impact Assessments (EIAs), natural resource management plans and environmental auditing. Most of these instruments are quasi-planning in nature normally deployed to complement the conventional land-use planning tools but largely outside the traditional planning practice. This points out that, in the mainstream planning activities, the emerging environmental management specialisations have increasingly drifted apart - theoretically, legally, administratively and in their specific responses to environmental problems. The irony of this compartmentalization is that urban planning largely grew out of the pragmatic concerns for the health of citizens and their social well-being in the wake of the industrializing cities of the nineteenth century. The growing magnitude of the negative environmental concerns impacting sustainable urban development must be redressed by 'operationalising' the symbiotic relationships between urban development and environmental management through the application of the relevant planning instruments.

In the study by Kapa (2005) on Lesotho's local government system, he stated that there was need for control of natural resources like sand and stones as well as environmental protection like pollution land/site allocation, water supply and market provision. Indecon (2005) in the review of local government financing in Ireland, stated that environmental protection expenditure was 695.2 million which was $19.2 \%$ of the total expenditure for 2004 and that water supply and sewerage consumed 450.6 million which was $12.5 \%$ of the total expenditure giving evidence that governments are responding to environmental challenges.

Local studies on environment accounting have been done. UNDP (2000) on its study on millennium development goals in Kenya stated that the current needs assessment recommended that it would take ksh 97,126,500 to develop and implement a strategy for integrating principles and practices of environmental accounting within and /or alongside the system of national accounting (SNA) - even if on a pilot basis. Ministry of youth affairs (2010) on environmental and social management framework (ESMF) stated that one of the key environmental and social issues in Kenya is health and environment and further explains that most of the urban areas in Kenya are faced by domestic waste and sewage management problems with only 32 out of the 175 local authorities having any form of sewage collection and disposal infrastructure. Nema (2005) in its strategic plan for 2005-2010 stated that there was lack of sewerage system and facilities for 143 out of 175 local authorities which led to increased cases of environmental health problems due to 
pollution of the ecosystem by heavy metals and chemicals such as nitrates. Waema and Mitullah (2007) in their study on e-governance in local authorities in Kenya stated that the LAIFOMS is limited to financial management and has only three main components, revenues, budgeting and financial management and expenditure, a study that fails to mention environmental accounting issues.

According to Kibeti (2004), Environmental costs are obscured in conventional accounts and yet they are real costs that should be accommodated by all firms and industries. Management of the environmental costs will result in improved environment, production and generally wealth of the urban population in the study area. This study would also argue for a clearer policy of the management of extractive industries and any other industry that largely tends to exploit natural resources. This will also contribute to the sustainability of the growth and development of not only the urban regions but also the rural. Being a pioneering study on one of the industries in an urban centre, other studies covering the various industries and regions will be encouraged. It is the ultimate purpose of this study to have other studies expanded to include all firms and sectors in the economy. To arrive at aggregates for the whole economy it is important to begin with the microeconomic production units. In his studies Hassan (1996) stated that in the coming decades, the continued urban population growth and especially the continued growth of the urban poor was expected to immensely challenge global sustainability. As at 2001, there were 43 cities in Africa with populations of more than one million and it is expected to increase to almost 70 by 2015 (UNPD, 2001). Nakuru would be among these cities. More problems of overcrowding, informal settlements, inadequate housing, poor infrastructure etc. are bound to increase. Infrastructural development has been slow in keeping pace with burgeoning needs of the urban population. Since most urban environmental problems result from poor management, poor planning and absence of coherent urban policies (Hassan, 1996); it is important that these dimensions be addressed in all sectors of the urban domain.

Another study by Hassan (2003) stated that the conventional national accounting systems, excludes: domestic production; products directly extracted from communal resources for household consumption and not traded in the market, and; benefits from ecological services, cultural, aesthetic, etc. Though GDP included income from extracted resources corresponding value of these assets lost to the economy was omitted. Depletion of natural and human capital was excluded from total national wealth of a nation and hence the measures of economic performance were wrong and misleading. Daly (1996) explained clearly that sustainable development sought to meet the needs of the present without compromising the needs of future generations. In other words, the present generation must leave the air, water and natural resources as pure and unpolluted as when it found it. Strong sustainability clarifies that in the case of renewable resources annual off-take must be kept equal to the annual growth increment while in the case of nonrenewals depletion should be at a rate equal to the development of renewal substitutes. That meant that stock of natural capital should not be reduced below a level that generated sustained yield unless good substitutes were then available. Hassan (2003) stated that sustainable development therefore, had to be financed in such a manner as to compensate for future depletion of exhaustible resources. He gave the example where policies had ensured sustainability from mining in South Africa, where the capital component $(\mathrm{CC})$ was fully reinvested in alternative forms of capital Hassan (2002). According to Dasgupta and Maler, the correct index of checking if development is sustainable is wealth. When accounting prices that reflect trade-offs among present and future well-beings and among contemporaries are used to determine well-being, wealth becomes a good index for showing whether development is sustainable or not. Poverty causes a society to elk out living through adverse exploitation of resources and this is the state of the populations in the Less Developed Countries (LDCs) (Dasgupta \& Maler, 1995).

Accounting for externalities has been adopted in the microeconomic level within the firm in hydroelectricity (EPA, 1996), health sector (EPA, 2000), chemical and oil companies (EPA, 1997a) and electroplating operations (EPA, 1997b) among others. The studies sampled, applied various environmental accounting techniques to evaluate environmental costs of economic activities in an industry. The results showed existence of positive environmental costs in all cases with an implication that most economics activities have environmental costs which are yet to be accounted for. Nema (2005), in its report stated that there were challenges that led to unsuitable management practices of ecosystems and their inherent biodiversity. Increased slum settlement in urban areas due to rapid rural-urban migration resulting in environmental problems of overcrowding, poor garbage disposal and environmental diseases like cholera, dysentery and typhoid.

Kisare (1999) in his studies on local government planning and management stated that there were increased environmental pollution and degradations resulting from uncontrolled industrial smoke-emissions, discharge of untreated industrial effluent into rivers, dumping of toxic waste and deforestation of peri-urban woodlands. 
In the annual report by the ministry of petroleum, the Egyptian general petroleum corporation(2000) stated that natural resource damages is a new category of environmental liability which had been established in the United States according to a number of regulatory such as the clean water Act and the oil pollution Act. Such resources include flora, fauna, land, air, and water resources. The liability can arise from accidental release as well as lawful release to air, water, and soil. As a result there was a wide range of environmental expenditures such as abatement costs, elimination costs and handling of waste costs just to mention but a few, as well as environmental capital expenditures as a result of buying a new and/ or new cleaner technology. Goals such as environmental costs optimization, better environmental performance, identifying the true (full) costs and identifying the social costs all require knowing the different current and potential costs. However the study further stated that knowing the environmental costs depended upon the organizational purpose for using such data like cost allocation, capital budgeting, product design and all that managerial decisions .the report ends by stating that the domain and scope of applying the costs if sometimes to be vague whether the costs are environmental or not.

SETAC (1993) on its report on a multi-disciplinary approach to solving problems of the impact of chemicals and technology in the environment stated that some companies were paying a significant portion of their total environmental costs to clean up pollution caused decades before like remediation costs related to superfund only being incurred by then but pertained of decades before that time. Due to the fact that the corporate environmental expenditures being often substantial, including them in the product costs affected the profitability of the products, facilities and divisions. Many companies according to the report include current operating costs pertaining to past environmental liabilities in their current product costs with the justification ,other expenses that created future benefits were charged to product costs or corporate overhead, including product development,reseach and development, and advertising expenses. Thus, current products benefited from those prior expenditures and the product costs must bear the costs related to prior production, just as it reaps the benefits. Therefore, from the above studies it is apparent that organizations are involved in environmental conservation costs and local authorities in Kenya are such kind of organizations that have both direct and indirect interactions with the immediate environment, thus, local authorities must incur environmental conservation costs. The studies point out that there is need to find out the various environmental conservation costs local authorities in Kenya go through.

\subsection{Accounting Theory}

The accounting theory has evolved through a long passage of time during which substantial changes in human behavior and market structures have taken place. The theory outlines how accountants have identified certain broad assumptions on which financial results of a business are prepared.These assumptions are called accounting concepts which define the rules under which financial statements of an entity should be prepared. The theory brings out boundary rules like entity, periodicity and going concern concepts to determine what should and should not be reported. Once the boundary is set, it should then determine how the accounting data should be recorded i.e. money measurement, historical cost, realization accruals, matching, duality and materiality. The theory limits the room for individual maneuvers, a number of ethical rules like prudence, consistence and objectivity have evolved, which suggest that there is a moral dimension in financial reporting.

\subsubsection{Green budgeting theory (in Environmental accounting in local government)}

It is by initiative of the local Agenda 21 (LA21), after the Rio summit (1992) and the Johannesburg summit (2002) that schemes of environmental accounting at sub-national levels of government started to be developed: a bottom-up approach., source of a large diversity of initiatives, in contrast to the top-down approach followed by nationals statistics offices coordinated, in addition, by supranational organizations such as the United Nations and Eurostat. Amidst the consequent fragmentation of local experiences, the only exception is the EcoBudget scheme, promoted by the International Council for Environmental Initiative (ICLEI), which has been implemented in more or less the same form by a few local governments in several countries. Its basic idea is to implement a budgeting system for natural resources that conforms to the community financial budgeting: the current institutions and procedures must provide the model for the budgeting of natural resources. It is based on environmental indicators and as such it does not aim to provide a monetary evaluation of the environment, or to maintain long term, detailed and systematic accounts to be used in policy design and programming. Rather, its purpose is to help monitoring the effectiveness of local governments in achieving the set targets in matter of environmental policy, and communicating objectives, achievements or failures between policy makers and citizens. In principle, the objective could be more ambitious: inserting environmental issues on the political agenda not in an ad hoc manner but rather as systematic reporting to the 
city/local council. The environmental master budget should confront the highest council decision-making committee with environmental and sustainable development issues. Local authorities should be able to predict, plan, control, monitor and report the consumption of natural resources, as part of their environmental management activities as called by the Aalborg Charter (1994), the Lisbon Action Plan (1996) and the Hanover Conference (2000). However, for these reasons, the potential of environmental accounting as an aid to economic programming and decision making, in general and at the local level in particular, is still largely underutilized. One of the features of environmental budgeting, as has been implemented, is flexibility in the choice of indicators - a choice that reflects, case by case, the interests and criticalities of specific local jurisdictions. It is in urban and suburban contexts, particularly, that the requirement of flexibility in resorting to the appropriate indicators in stronger .on the one hand, composing the menu of indicators in response to specific geographical and social context may appear sensible and pragmatic choice. On the other hand, it is difficult to set up a real, consistent accounting system over time when local governments' priorities and programs change, because the indicators will also change as a consequence.

\subsubsection{Environmental accounting used to estimate optimal extraction levels for quarries: a case of Nakuru municipality.}

The common aggregate measures of economic performance include Gross Domestic Product (GDP), National Income (NI) and level of employment. However, these indicators ignore natural resources and environmental factors. Though resources and the environment as a whole is not included in the National accounts, changes in the two items contribute to production and income; and must therefore be accounted for. The welfare of the nation's population present and more especially in the future will be greatly determined by the stock of natural resources available and the quality of environment. Currently, the production processes generally degrades the environments and depletes natural resources. This implies that the system of national accounting used, seriously under-estimates changes in the stock of natural resources and the environment of a nation Kibet (2004).

\subsubsection{The Green Towns Environmental Project}

The project was carried out with its objective to initiate a process of environmental awareness among local authority managers, decision makers and the public so as to come out with an environmental development plan of a given town. The project also does the planning on community participation basis. Towns like Malindi and Eldoret are examples of places where the projects have been applied successfully (Kisare 1999).

\subsubsection{Current environmental issues on air pollution}

According to JICA (2002) report on Kenya's profile on the environment, air pollution is not monitored at specific sites, and there are no data on the calculation of annual pollutant emissions. However, from various studies carried out in some parts of the country, air pollution has serious impacts on the environment and health of Kenyan populace. According to these studies, the main air pollutants in major cities such as Nairobi, Mombasa, Nakuru, Eldoret, Thika and other small ones like Webuye, Kikuyu and Limuru just to mention but a few are the suspended particulate matter (SPM), Lead oxide of sulphur, carbon monoxide, hydrogen and oxides of nitrogen. There are no set standards for most of these pollutants. But studies show that levels of some of these pollutants in some towns far exceed the WHO or other international standards.

\subsubsection{The Contingency theory}

This approach advocates that there is no one 'best' design for a management accounting information system, but that "it all depends" upon the situational factors (Drury 2004, page 696). Headquarters and business units respond upon the business environment and settle their Management Accounting System. Headquarters delegate responsibilities to the BU-managers. Based upon these responsibilities, and the corporate characteristics, the BU-managers set their demand for information from their BU-controllers, and adjust their demand for information to their own business unit characteristics. This demand for information is sent to the BU-controller. As the literature on role theory indicates, "role" is a useful tool for examination of the position of the controller as it links three central concepts: role expectations ( what the BU-manager and BU-controller believe he should do); role behavior ( what he actually does ) and how is position is linked to others, thus shaping his "role set" (Gross et al. 1958 ). Shaping his role set, is answering the question: why do BU-controllers behave in a certain way? Role theorists may say they share expectations for their own behavior and that of others (Biddle 1972 page 115). Thus BU-controllers "expect" that BUmanagers want to have a bonus and they "expect" that the corporate controllers want to receive the proper information of business unit performance. There could be a gap or difference between the demand for information by the BU- 
manager and the supply of information by the BU-controller. This gap can be explained by the differences between the sender and the receiver, by role theory, the interpersonal relationships, and the differences between BU-manager's and BU-controller's personality and expectations (Kahn et al. 1964). The contingency factors which influence the demand- side are related to: corporate management, environment, business, corporate controller characteristics, and manager's expectations and expertise.

\subsubsection{Institutional theory}

According to Dillard et al.(2004,p.508), "an institution is an established order comprising rule-bounded and standardized social practices, and institutionalization is the process whereby the practices expected in various social settings are developed and learned." Further, institutional theory is chiefly concerned with an organization's interaction with the institutional environment, the impacts of external expectations on the organization, and the combination of these expectations as reflected in the organizational practices (Martinez, 1999). Hence, under this theory, organizations will change their structures or operations to comply with external expectations about what structures are seen as appropriate (Deegan, 2002). In order to achieve legitimacy, organizations do not necessarily consider only what one organization is actually doing, but also the need to accommodate what potentially influential publics are doing. Institutional theory has been widely applied in accounting research to study the practice of accounting in organizations. The institutional framework has provided useful insights into the practice of accounting in organizations. The institutional theory based accounting research comprehensively represents accounting as the object of institutional practices and attempts to provide a better understanding of institutions, accounting practices and change processes. Institutional theory has wide applicability, which can be used to analyze all types of organizations because all organizations are institutionalized organizations.

\subsubsection{Stakeholder theory}

The stakeholder approach to analysis is well established in management accounting literature (Roberts, 1992). Its essence is the definition of all those groups or parties who are influenced by and /or who influence the organization or accounting entity .From this point on stakeholder theory struggles to maintain anything other than an organizationcentred legitimacy because while the groups may be defined with a fair degree of objectivity, who (other than the organization) is left to define the priorities among the stakeholders and the information that should be disclosed to each one? Stakeholder's theory, therefore, is concerned typically with how the organization manages its stakeholders. Thus, information disclosed to the stakeholders may be assumed more properly by the organization to be part of legitimacy. Stakeholder's theory is relatively silent on how the organization does -if it all -monitor and respond to the needs of the stakeholders. It will do so, generally speaking, when it is in the organization's traditional interests to do so.

\subsection{Empirical studies}

In recent years a number of empirical studies have been published which use not only more detailed data about solid waste services but also progressively more sophisticated statistical techniques. Reeves and Barrow (2000) worked with a sample of 48 municipalities in Ireland and usedinformation covering the years 1993, 1994 and 1995. Taking as their explained variable the total cost of waste services they considered a series of explanatory variables related to output and other service characteristics such as the number of collection units (approximation to output), as well as variables regarding service frequency, the type of collection, the importance of costs derived from selective waste, residential density, and whether or not delivery was public or private. On the basis of their empirical analysis Reeves and Barrow (2000) argue that private delivery was associated with cost savings in each of the years studied, and also that these savings were very high. Callan and Thomas (2001) considered the possible multi-product nature of solid waste services, distinguishing between their two main components: general waste for disposal and selective waste for recycling. The empirical analysis was based on a sample of 110 municipalities in Massachusetts (USA), using information for the year 1997. Callan and Thomas estimated a two-equation model in which the explained variable was service cost (of disposal, on the one hand, and recycling on the other), while the explanatory variables were the amount of waste generated, the population density, the frequency of collection, the form of service delivery (public monopoly or contracting out), and the existence of a municipal dump, among others. In the case of waste for disposal the empirical analysis revealed economies of density but no economies of scale, whereas for recyclable waste there were economies of scale but no economies of density. The authors also found economies of scope for both disposal and recycling services. A greater collection frequency was associated with higher costs in both cases, while the 
existence of a municipal dump reduced costs. Finally, the form of delivery had no effect on cost (Callan \& Thomas, 2001).

Dijkgraaf and Gradus (2003) studied solid waste service costs in a sample of 85 municipalities in the Netherlands for the period 1996-97. Taking total service cost as theirexplained variable the authors assumed coverage of $100 \%$ by means of taxes and estimated costs as the product of service taxes and the number of households. The variables used to explain total costs were related to service output, for example, the number of collection points, the density of collection points and the type of collection. They also considered the frequency of service and variables that reflect recycling characteristics such as the percentage of glass, paper and organic matter. Finally, a distinction was made between public and private service delivery. This study also made use of the Chow test, which measures the structural stability of cost equations. Dijkgraaf and Gradus (2003) compared the structural stability of the cost equation for both the size of municipality and the form of delivery. As regards costs according to the model of delivery the authors found that contracting out was associated with lower costs, although there were no significant differences between public and private delivery in this respect.

The studies by Bel (2006) and Bel and Costas (2006) constitute the first econometric Analyses in Spain of the municipal costs of solid waste services. The research used a sample of 186 municipalities in Catalonia and the information gathered was for the year 2000. In order to explain the total cost of solid waste services, these works consider variables related to the volume of product (amount of waste generated), the price of inputs (wage costs), certain characteristics of the product (frequency of the service, availability of dumping sites, form of production, i.e. public or private), and certain uncontrollable characteristics that affect the service, such as population density and the strength of the tourist factor. In general, these explanatory factors are in line with those used in the abovementioned studies, although the specification of a tourism variable, based on the degree of such activity, is a novelty in the literature. The empirical analysis found significant economies of scale in the less-populated municipalities. However, the strength of these economies of scale was limited and, indeed, both their intensity and significance disappeared as population increased. In fact, the test of structural change indicated the advisability of studying larger municipalities separately from smaller ones. As regards the association between form of production and service costs there were no significant differences between public and private delivery.

Finally, Dijkgraaf and Gradus (2007) analyzed the factors which determined the total costs of waste services in 453 municipalities in the Netherlands for the year 2002. This study used the same control variables as those employed by Dijkgraaf and Gradus (2003) to explain total costs of service delivery at the municipal level: number of collection points, density of collection points, type of collection, frequency of service, characteristics of recycling, and form of production. Additionally, they included a series of concentration indicators at the provincial level to analyze the extent to which the strength of competition affects the impact of contracting out on costs, taking into account that in the Netherlands contracting out may involve both public and private companies. The concentration indicators used were the Hirschman-Herfindahl index, the C3-ratio (the market share of the three largest companies) and the presence of competitors (private or public) in municipalities within the same geographical area. Although the results for the other explanatory variables were very similar to those reported by Dijkgraaf and Gradus (2003) the authors found evidence to suggest that cost savings with contracting out depended on the degree of concentration at the provincial level: the greater the concentration the lower the cost savings associated with contracting out. In addition, they found that the presence of public (but not private) companies as competitors in neighboring municipalities seemed to have a positive effect on the cost savings achieved with contracting out.

An environmental conservation cost is a complex activity that cannot fully be explained by a single theoretical perspective or from a single level resolution. Conceptual theories of environmental conservation costs should therefore, be fully embraced in order to enhance solid understanding of environmental conservation costs by organizations. Organizations have used environmental conservation costs and should continue to positively use it as means to attain their overall environmental management systems.

\section{Methodology}

The section outlines the research design and methodology followed in conducting this study. It describes the entire process that the researcher followed to obtain the sample from the population as well as the data collection methods, and data analysis. 


\subsection{Research Design}

The design was a survey which involved gathering, processing and interpreting data collected from the 90 Local authorities in Kenya. The design was valuable for detailed analysis. Young (1960) and Kothari (1990) concur that the study provides valuable insights to a phenomena that may be vaguely known and less understood. Kalunda (2007) used the same design in his successful studies on corporate reporting.

\subsection{Population of study}

The population of study was made up of the 175 local authorities in Kenya.

\subsection{Sample of the study}

The sample of the study was made up of 90 Local Authorities selected randomly. This was to avoid biasness.

\subsection{Data collection instruments}

The study used both primary and secondary data. Primary data was collected by way of questionnaires while the secondary data was obtained from the local authority records.

\section{Data analysis and Findings}

Secondary data was analyzed using the statistical package for social sciences (SPSS) version 17 and Excel. The data compared the costs allocated to various activities using the available funds with the costs allocated to the activities by each LA. Primary data from the questionnaires was analyzed to explain actual costs spent on each activity by individual LAs. The results are through the use of descriptive statistics like frequency distributions, bar graphs and pie charts showing how the LAs spent their revenues on environmental conservations.

\subsection{Expenditure per local authorities studied}

The bar graph below shows the total expenditure per local authority in terms of environmental conservation cost

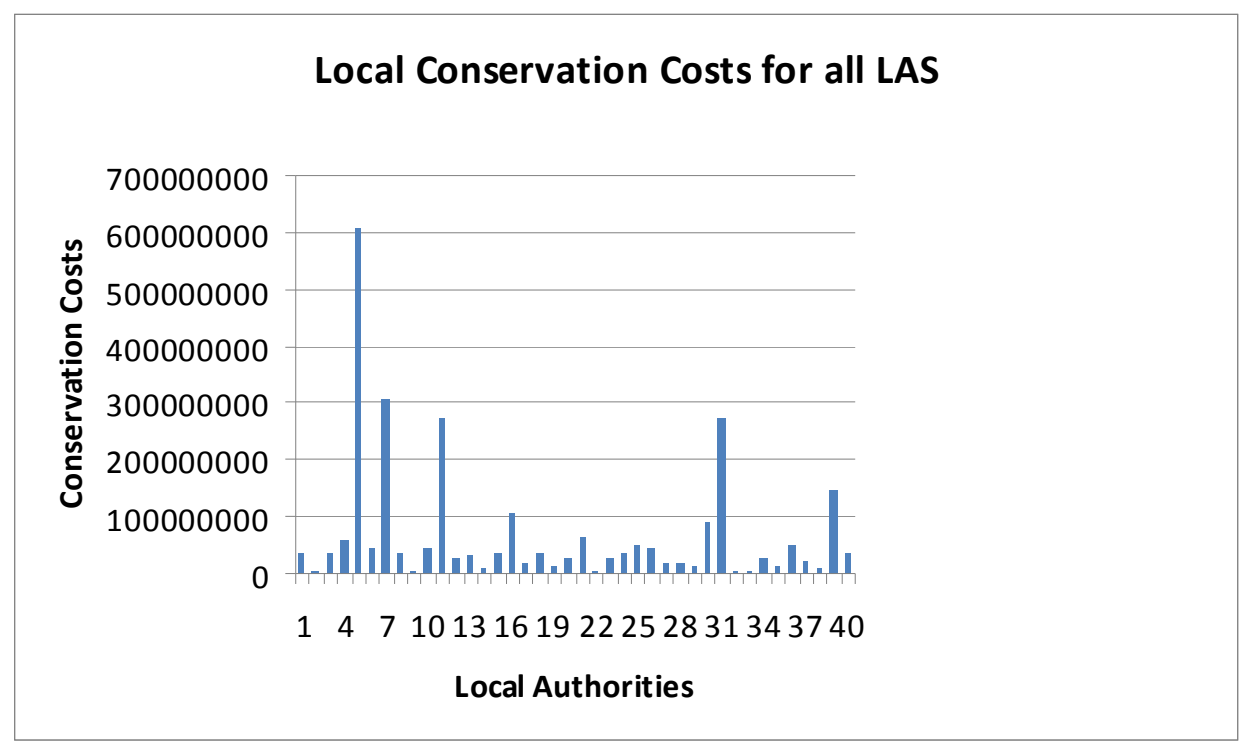

Fig1: Bar graph of Conservation costs for all LAS.

Source: MLG.circular no. 4/2009

From the graph, it can be inferred that:

Five local authorities had used environmental conservation costs more effectively than the others as evidenced by both their highest means as well as their standandard deviations. These local authorities were nairobi city council,kisumu municipal, Narok county council, Eldoret municipal council,and Mombasa in that order respectively. 
Five other local authorities on ther hand used the least environmental conservation costs in a less effective way as they scored lowest in terms of the mean and the standard deviations. These LAs were Chogoria town council,Port Victoria town council, Oyugis town council, Kwale town council and Ijara county council in the order respectively.

\subsection{Sources of revenues to the local authorities}

From the analysis local authorities are allocated each a flat rate figure of sh 1.5 million and the other allocations to the local authorities are given by the ministry depending on individual local authorities' population. Apart from these allocations other sources of revenue are RMLF and CILOR besides donations from donors that are used to assist the local authorities finance their operations.

\subsection{Rationale for the distribution of the revenues into various activities in all local authorities.}

The analysis clearly shows that the administrative activity is carried out by almost all the local authorities that were studied. Other local authorities' activities like pollution prevention activity, global conservation activity, resource circulation activity, social activity and remediation activity are performed according to individual local authority' choices and priority depending on local needs

\section{Discussions}

\subsection{Operations of local authorities in Kenya}

From the analysis local authorities operate the same way under the same administrative structure which is mainly financed by the same sources of revenue. All the 175 local authorities are supervised by ministry of local government where they file their annual financial reports with the same ministry.

\subsection{Environmental conservation costs in LAs}

The analysis clarify that the activities in which LAs carried out in their operations incur costs that are spent to maintain clean and healthy environment within these individual local authorities. The allocation of revenue to the local authorities according to their population size plays a great deal in dictating the amounts received and spent by each LA. Thus, local authorities with highest population benefiting with the highest allocations and hence are able to have many of their environmental conservation activities carried out in their operations. This is unlike the less populous LAs which receive small allocations and finally do less on their environmental conservation activities.

\section{3 the relationship between the amounts allocated and the number of conservation activities in LAs}

The analyses indicate that the numbers of environmental conservation activities have costs spent on them per LA are affected by amounts allocated on the basis of population data. Due to that biasness in allocation, some environmental conservation activities in less populous LAs go unfunded or with little funds. Out of the LAs studied the top five local authorities in terms of averages and standard deviations in the way they financed their environmental conservation activities were Nairobi city council, Kisumu municipal council, Narok county council, Eldoret municipal council and Mombasa municipal council respectively. The bottom five LAs in terms of averages and standard deviations were Chogoria town council, Port Victoria town council, Oyugis town council, Kwale town council and Ijara county council respectively.

The variation in the analysis was brought by the uneven distribution and allocation of revenues by the ministry of local government following population data as the only criteria of financing the 175 LAs.

\section{Conclusions}

All the studied local authorities were found to allocate environmental conservation costs into their activities to prevent, reduce or even to avoid environmental impact and therefore environmental costs are evident. Despite the fact that all LAs use conservation costs, the degree of application of the costs is not uniform in all the local authorities.

Therefore, the allocation of revenue by the ministry of local government to LAs should be even and not necessarily based on population data. Even allocations are likely to lead to each of the LAs spending equal amounts on their various environmental conservation activity costs.

Environmental conservation activity costs have been evidently applied by the local authorities. However, the degree and extent of application can be enhanced if the basis of allocation is made equal and the MLG out lines guidelines 
that emphasis on every conservation activity to be financed with specific amounts and not to leave the decision on the activities' financing to individual LAs.

Out of the sample of 90 LAs only 41 (45.6\%) responded. Most town/ county clerks were involved in seminars outside their local authorities that led to other officers being the respondents in the individual LAs.

Future research may be directed to the relationship between costs in other activities carried out by local authorities in Kenya. In addition, since local authorities may have different financial needs more research can be done on the rationale to base the allocation of revenues on one aspect of population data which has given some LAs advantage over others in the way they have used their environmental conservation activity costs.

Environmental conservation activity costs have been evidently applied by the local authorities. However, the degree and extent of application can be enhanced if the basis of allocation is made equal and the MLG out lines guidelines that emphasis on every conservation activity to be financed with specific amounts and not to leave the decision on the activities' financing to individual LAs.

Further research can be done to find out why there are no uniform guidelines that govern environmental conservation costs in all the 175 LAs in Kenya.

\section{Acknowledgements}

First, a very special and enormous thank to my supervisor, Mr. N.T.T.Simiyu for his guidance, invaluable expertise, friendship and support through out the journey. I also want to express my gratitude to other members of the department of Finance and Accounting, and other people I have met along the way, for their support and encouragement.Finally, thanks to my families, especially wife, parents and brothers for their endless support and love all the time.

\section{References}

Aalborg Charter (1994)

Bailey P.E, (1991). Full cost accounting for life cycle costs.

Bel, Gama and Costas A. (2006). "Do public sector reforms get rusty? Local privatization in Spain," Journal of public reform, 9, pp.1-24.

Bennett, M., James, P., (1998). Environment under the Spotlight-Current Practice and Future Trends in Environment-Related Performance Measurement for Business. Association of Chartered Certified Accountants, London

Biddle, B.J. (1972). Role theory: Expectations, Identities, and Behaviors, New York, Academic

Press, (ISBN 0-12-095950-X), pp. 416.

Callan, Thomas .M. (2001).” Economics of scale and scope. A cost analysis of municipal solid

waste services," land economics, 77, pp.548-560. Correspondent, Shell international, at: www.shell.com/financial correspondent.

Deegan, C and Gordon, B. (1996), “A study of the environmental Disclosure practices of Annual

Reports," Accounting and Business Research, vol.26, No.3, pp.187.

Dijkgraaf, Gradus (2003). “Cost savings of contracting out refuse collection,” Empirical, 30, pp. 149-161.

Dijkgraaf, Gradus (2007). “Collusion in the Dutch waste collection market,” local government studies, 33, pp. 573588.

Daryl D, Ranganathan J, Daryl, (1995). Green Ledgers, case studies in corporate environmental accounting.

Dorweiler VP, Yakhou M (2002). Dimensionality of environmental accounting. Journal of accounting and finance research, no.9 (4), pp 47-64. 
Drury, C. (2004). Management and Cost Accounting, 6th edition, London, Thomson Learning (ISBN 1-84480-028-8), $1280 \mathrm{pp}$.

Savage .E. "Environmentally Smart Accounting: using Total Cost Assessment to advance pollution prevention," pollution prevention Review (Summer 1993), pp.247-259. Economic Accounting. , New York.

EPA (1997b). Applying environmental accounting to electro planting operations; An In Depth analysis, US environmental protection agency (EPA), Washington DC.

Edvinsson, L.Malone MS. (1997). Intellectual Capital: Realizing Your Company's True Value by Finding Its Hidden Brainpower, Harper Business; New York.

EPA (1997a).Environmental cost accounting for chemical and oil companies: A bench marking study. US environmental protection Agency (EPA), Washington DC.

Farghally, Ahmed, (1997).Future Studies in Environmental Accounting

Global Reporting Initiative (2002)

Gross, N, Mason, WS \& MC Eachern, A.W (1958). Explorations in Role Analysis: studies of the school superintendence role, New York, John Wiley \& Sons, Inc; (ISBN 471-32802-2), PP.379.

Gulch. P. (2000). Costs of environmental errors. Greener management international autumn Pp 23-36.

Hannover Conference (2000)

Hassan, R.M. (1996). Defining environmental information, its economics and usefulness in decision making. A survey of the economics of environmental information, IS donors and sustainability in Africa, EIS, and news.

Hassan R.M. (2003). Accounting for the environment; experiences from Southern Africa. Ecological and environmental economics program (EEEP).

Hope, J.Hope T. (1998). Competing in Third Wave: the Ten key management Issues of Information Age .Harvard Business school: Boston, MA.

Indecon, (2005). Indecon Review of Local government Financing. International Institute of Social and Ethical Accountability (ISEA), (1999). Accountability 1000 (AA1000) Framework

Johannesburg Summit (2002)

JICA (2002). Kenya profile on environment.

Kahn, R.L., Wolfe, D.M., Quinn, R.P., Snoek, J.D \& Rosenthal, R.A. (1964). Organizational Stress: studies in role conflict and ambiguity, New York, John Wiley \& Sons Inc., (ISBN 0-89874-8-07), pp.470.

Kapa M.A, (2005). Lesotho's local government system: A critical note on the structure and its implications for popular participation and service delivery.

Kibeti K.L (2004). Use of environmental accounting to estimate optimal extraction levels for quarries: a case of Nakuru municipality.

Kisare, S.M (1999). Local government planning and management for Eastern and Southern Africa: Strategic planning Experiences in Kenya

Local government Act (1963). Local government Act caps 265 laws of Kenya.

Leeds ECO, "Leeds Ecological Footprints, ” at www.gn.apc.org/eco/evievw/lefbref2

Lehman D.O, (2000). Social and Environmental Accounting, trends and directions for the future.

Lisbon Action Plan (1996)

Mazhindu, E, (2009). Local government processes and the Environment in Africa: Issues, perspectives and practicalities. 
Medley P. (1997). Environmental accounting- what does it mean to professional accountants? Accounting, auditing and accountability pp 594-600.

Ministry of youth affairs Kenya (2010).Environmental and Social management policy framework

Ministry of local government Kenya (2009). Guidelines for preparing budget estimates and accessing local authorities transfer fund monies.

Nema (2005) Strategic plan 2005-2010, abridged version.

Pateman, C, (1970). Participation and Democratic Theory. Cambridge: Cambridge University press. Pretoria: H\&R Academica (pty) Ltd.

Pearce, David, (1994). Measuring Sustainable Development. Earth scan

Porter, ME. \& Kramer, MR. (2006). “Strategy \& Society,” Harvard Business Review, vol.82,

No.12, pp.78-92.

Reeves, Barrow .M. (2000). "The impact of contracting -out on the costs of refuse collection services. The case of Ireland," Economics and social review .31, pp. 129-150.

Riode Janeiro summit (1992).

Simpson, (1995). Sustainable development issues for Brisbane and South and East Queensland

Region.

United Nations, (1994). "'System of Integrated Environmental and Economic Accounting, New York.

UNDP (2000).Millennium development goals in Kenya needs and costs.

UNPD (2001). World urbanization prospects: The 1999 revision - key findings. United Nations

population division (UNDP).

Waema T.M \& Mitullah W.V. (2007). E-governance in local authorities 


\section{Appendix Nomenclature}

\begin{tabular}{ll} 
BU & Business Unit \\
CC & Capital Component \\
CILOR & Contribution in lieu of rates \\
EIAS & Environmental impact assessment \\
EPA & Environmental protection agency \\
ESMF & Environmental and social management framework \\
FASB & Financial accounting standard \\
GAAP & Generally accepted accounting principles \\
GDP & Gross domestic product \\
ICLEI & International council for environmental intitiative \\
ISEA & Institute of social and ethical accountability \\
ISO & International organization for standardization \\
JCA & Japanese International Corporation \\
LA & Local Authority \\
LAIFORMS & Local authority integrated financial operations management system \\
LATF & Local authority trasferfund \\
LCDs & Less developed countries \\
MLG & Ministry of local government \\
NI & National Income \\
RMLF & Road maintenance levy fund \\
SEC & Security exchange commission \\
SETAC & Socity of environmental toxicology and chemistry \\
SNA & System of national accounting \\
SPM & Suspended particulate matter \\
UK & United Kingdom \\
UNDP & United Nations development programme \\
UN & Unitions \\
\hline
\end{tabular}

